\title{
Wall-eyed bilateral internuclear ophthalmoplaegia (WEBINO) from a paramedian mesencephalic infarct
}

\author{
Bik Ling Man, Man Sum Chi, Yat Pang Fu
}

Department of Medicine and Geriatrics, Tuen Mun Hospital, Hong Kong, Hong Kong

\section{Correspondence to} Dr Bik Ling Man, beli_man@yahoo.com

Accepted 30 September 2015

\section{DESCRIPTION}

An 84-year-old man with a history of hypertension, diabetes mellitus and ischaemic heart disease, was admitted for sudden onset binocular diplopia and unsteady gait. Physical examination showed primary gaze exotropia of both eyes (figure 1), bilateral internuclear ophthalmoplaegia and impaired vertical gaze of his right eye (video 1 ). Convergence, saccades and smooth pursuit were impaired. Vestibulo-ocular reflex was normal. Pupillary and levator function was normal. MRI of the brain revealed a paramedian mesencephalic infarct (figure 2). The patient's condition improved significantly after treatment with aspirin and rehabilitation therapy.

Wall-eyed bilateral internuclear ophthalmoplaegia (WEBINO) is a rare neuro-ophthalmological condition characterised by dissociated abducting nystagmus, impaired convergence and supranuclear vertical gaze palsy. ${ }^{1}{ }^{2}$ It is caused by a midbrain lesion damaging the bilateral medial longitudinal fasciculus and pretectum, which is supplied by the anteromedial perforators of the posterior cerebral artery. $^{2}$

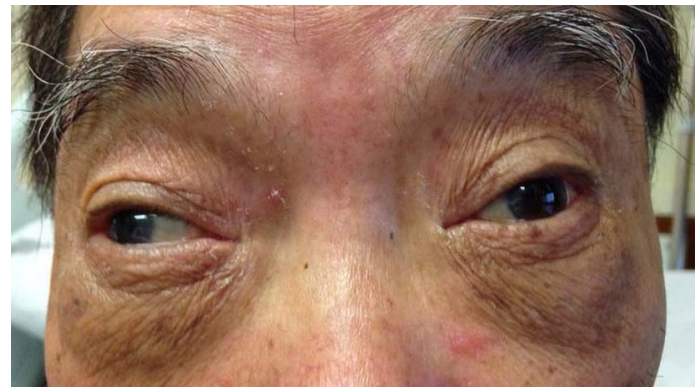

Figure 1 Primary gaze exotropia of both eyes.

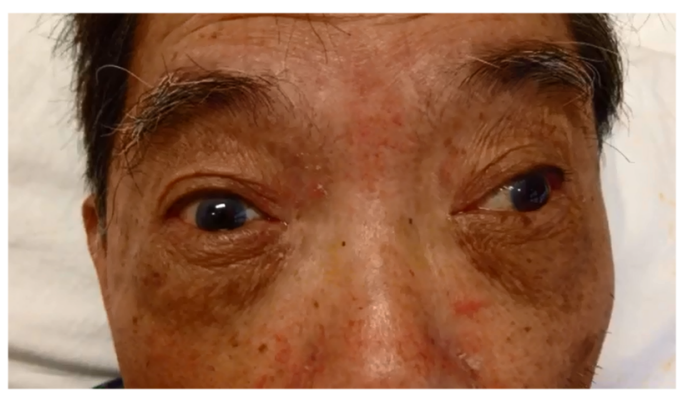

Video 1 Bilateral internuclear ophthalmoplaegia.

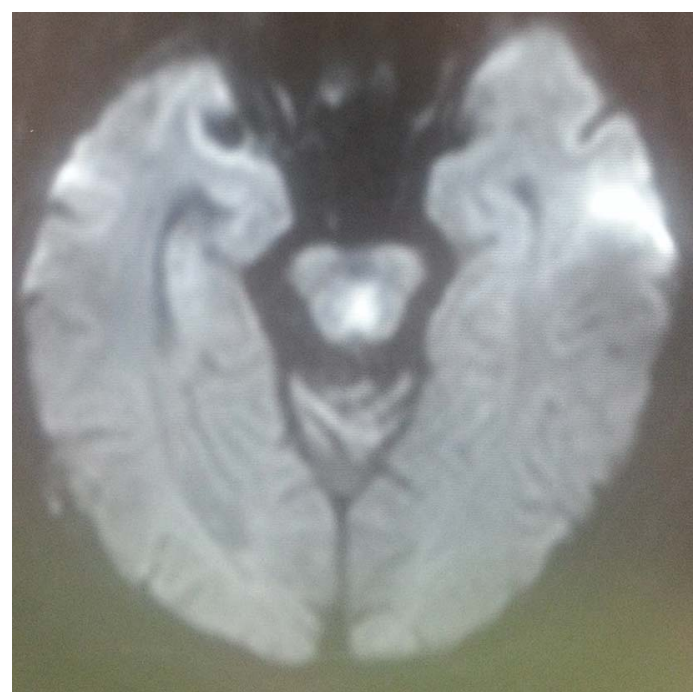

Figure 2 MRI DWI image shows an infarct in paramedian midbrain. DWI, diffusion weighted imaging.

\section{Learning points}

- Wall-eyed bilateral internuclear ophthalmoplaegia (WEBINO) is a rare neuro-ophthalmological condition characterised by dissociated abducting nystagmus, impaired convergence and supranuclear vertical gaze palsy.

- It is caused by a midbrain lesion damaging the bilateral medial longitudinal fasciculus and pretectum, which is supplied by the anteromedial perforators of the posterior cerebral artery.

Competing interests None declared.

Patient consent Obtained.

Provenance and peer review Not commissioned; externally peer reviewed.

\section{REFERENCES}

1 McGettrick P, Eustace P. The W.E.B.I.N.O. syndrome. Neuro-ophthalmology 1985;5:109-15.

2 Kim JS, Jeong SH, Oh YM, et al. Teaching Neurolmage: wall-eyed bilateral internuclear ophthalmoplegia (WEBINO) from midbrain infarction. Neurology 2008;70:e35. 
Copyright 2015 BMJ Publishing Group. All rights reserved. For permission to reuse any of this content visit http://group.bmj.com/group/rights-licensing/permissions.

BMJ Case Report Fellows may re-use this article for personal use and teaching without any further permission.

Become a Fellow of BMJ Case Reports today and you can:

- Submit as many cases as you like

- Enjoy fast sympathetic peer review and rapid publication of accepted articles

- Access all the published articles

- Re-use any of the published material for personal use and teaching without further permission

For information on Institutional Fellowships contact consortiasales@bmjgroup.com

Visit casereports.bmj.com for more articles like this and to become a Fellow 